\title{
Colon Signet Ring Cell Adenocarcinoma
}

National Cancer Institute

\section{Source}

National Cancer Institute. Colon Signet Ring Cell Adenocarcinoma. NCI Thesaurus. Code C7967.

An invasive adenocarcinoma of the colon characterized by the presence of malignant glandular epithelial cells which contain prominent intracytoplasmic mucin (signet ring cells). The signet ring cells constitute more than $50 \%$ of the malignant cells. 